\title{
Mars ISRU for Production of Mission Critical Consumables - Options, Recent Studies, and Current State of the Art
}

\author{
Gerald B. Sanders ${ }^{1}$, Aaron Paz ${ }^{2}$, Lara Oryshchyn ${ }^{3}$, and Koorosh Araghi ${ }^{4}$ \\ NASA, Johnson Space Center, Houston, TX, 77058, USA \\ Anthony C. Muscatello 5 \\ NASA Glenn Research Center Cleveland, OH, 44135, USA \\ Diane L. Linne ${ }^{6}$, and Julie E. Kleinhenz ${ }^{7}$ \\ NASA Kennedy Space Center, FL, 32899, USA \\ and \\ Todd Peters ${ }^{8}$ \\ Jacobs Engineering, Houston, TX, 77598, USA
}

In 1978, a ground breaking paper titled, "Feasibility of Rocket Propellant Production on Mars" by Ash, Dowler, and Varsi discussed how ascent propellants could be manufactured on the Mars surface from carbon dioxide collected from the atmosphere to reduce launch mass. Since then, the concept of making mission critical consumables such as propellants, fuel cell reactants, and life support consumables from local resources, commonly known as In-Situ Resource Utilization (ISRU), for robotic and human missions to Mars has been studied many times. In the late 1990's, NASA initiated a series of Mars Human Design Reference Missions (DRMs), the first of which was released in 1997. These studies primarily focused on evaluating the impact of making propellants on Mars for crew ascent to Mars orbit, but creating large caches of life support consumables (water \& oxygen) as a backup for regenerative life support systems for long-duration surface stays ( $>500$ days) was also considered in Mars DRM 3.0. Until science data from the Mars Odyssey orbiter and subsequent robotic missions revealed that water may be widely accessable across the surface of Mars, prior Mars ISRU studies were limited to processing Mars atmospheric resources (carbon dioxide, nitrogen, argon, oxygen, and water vapor). In December 2007, NASA completed the Mars Human Design Reference Architecture (DRA) 5.0 study which considered water on Mars as a potential resource for the first time in a human mission architecture. While knowledge of both water resources on Mars and the hardware required to excavate and extract the water were very preliminary, the study concluded that a significant reduction in mass and significant enhancements to the mission architecture were possible if Mars water resources were utilized. Two subsequent Mars ISRU studies aimed at reexamining ISRU technologies, processing options, and advancements in the state-of-the-art since 2007 and to better understand the volume and packaging associated with Mars ISRU systems further substantiated the preliminary results from the Mars DRA 5.0 study. This paper will provide an overview of Mars ISRU consumable production options, the analyses, results, and conclusions from the Mars DRA 5.0 (2007), Mars Collaborative (2013), and Mars ISRU Payload for the Supersonic Retro Propulsion (2014) mission studies, and the current state-of-the-art of Mars ISRU technologies and systems. The paper will also briefly discuss the mission architectural implications associated with Mars resource and ISRU processing options.

\footnotetext{
${ }^{1}$ ISRU Chief Engineering, Energy Conversion Systems Branch, EP3, AIAA Member.

${ }^{2}$ ISRU Engineer, Energy Conversion Systems Branch, EP3, AIAA Member.

${ }^{3}$ Engineer, Energy Conversion Systems Branch, EP3, AIAA Member.

${ }^{4}$ Fuel Cell and Electrolysis Technology Manager/PI, Energy Conversion System Branch, EP3, AIAA Member.

${ }^{5}$ Chemist, Applied Science, UB-R3, non AIAA member.

${ }^{6}$ Senior Research Engineer, Propulsion Division, MS 301-3, AIAA Associate Fellow.

${ }^{7}$ Research Engineer, Propulsion Division, MS 301-3, AIAA Senior Member.

${ }^{8}$ Manager, Enery Systems Test Area, EP6, non AIAA Member.
} 


\section{Mars ISRU for Production of Mission Critical Consumables \\ - Options, Recent Studies, and Current State of the Art}

Sept. 1 ${ }^{\text {st }}, 2015$

\section{AIAA Space 2015 Conference, Pasadena, CA}

G. B. Sanders ${ }^{1}$, A. Paz ${ }^{1}$, L. Oryshchyn ${ }^{1}$, K. Araghi', A. Muscatello²,

D. Linne ${ }^{3}$, J. Kleinhenz ${ }^{3}$, and T. Peters ${ }^{4}$

1. NASA Johnson Space Center, Houston, TX,

2. NASA Kennedy Space Center, KSC, FL

3. NASA Glenn Research Center, Cleveland, $\mathrm{OH}$

4. Jacobs Engineering, Houston, TSX 


\section{Mars ISRU Mission Studies}

- Past Mars Studies with ISRU (DRM 1 to 4)

- Only considered atmospheric resources were available $\left(\mathrm{CO}_{2}, \mathrm{~N}_{2}, \mathrm{Ar}\right)$

- Evaluated two propellant production options

- Make Oxygen $\left(\mathrm{O}_{2}\right)$ only and bring fuel from Earth

- Make $\mathrm{O}_{2}$ and methane $\left(\mathrm{CH}_{4}\right)$ with hydrogen $\left(\mathrm{H}_{2}\right)$ brought from Earth

- Produced various amounts of life support consumables as backup

- Ex. DRM 3: $4500 \mathrm{~kg}$ of $\mathrm{O}_{2} ; 3900 \mathrm{~kg}$ of $\mathrm{N}_{2} ; 23,200 \mathrm{~kg}$ of water $\left(\mathrm{H}_{2} \mathrm{O}\right)$

- ISRU considered only after performing non-ISRU scenario

- No change in Mars entry or rendezvous orbit compared to non-ISRU scenario

- Influence of ISRU consumable availability or technologies not considered on other systems

- Decisions made on basis of mass/power comparisons. Did not evaluate volume required for ISRU hardware or hydrogen delivered from Earth

\section{- Recent Mars Studies with ISRU}

- Considered both atmospheric $\left(\mathrm{CO}_{2}, \mathrm{~N}_{2}, \mathrm{Ar}\right)$ and soil $\left(\mathrm{H}_{2} \mathrm{O}\right)$ resources based on increasing knowledge from Mars Odyssey and subsequent missions

1. Mars Design Reference Architecture (DRA) 5.0 - 2007

- First study to consider water as a resource; understanding of water on Mars and ISRU hardware for soil excavation and processing was very preliminary

2. Mars Collaborative Study (HEOMD, STMD, SMD) - 2013

- Increased understanding of water on Mars and ISRU hardware needed for soil processing based on lunar ISRU development and ISRU analog field test experience

3. Mars ISRU Payload for Supersonic Retro Propulsion (SRP) Mission - 2014

- First study to examine volume/packaging of ISRU production options 


\section{The Chemistry of Mars ISRU}

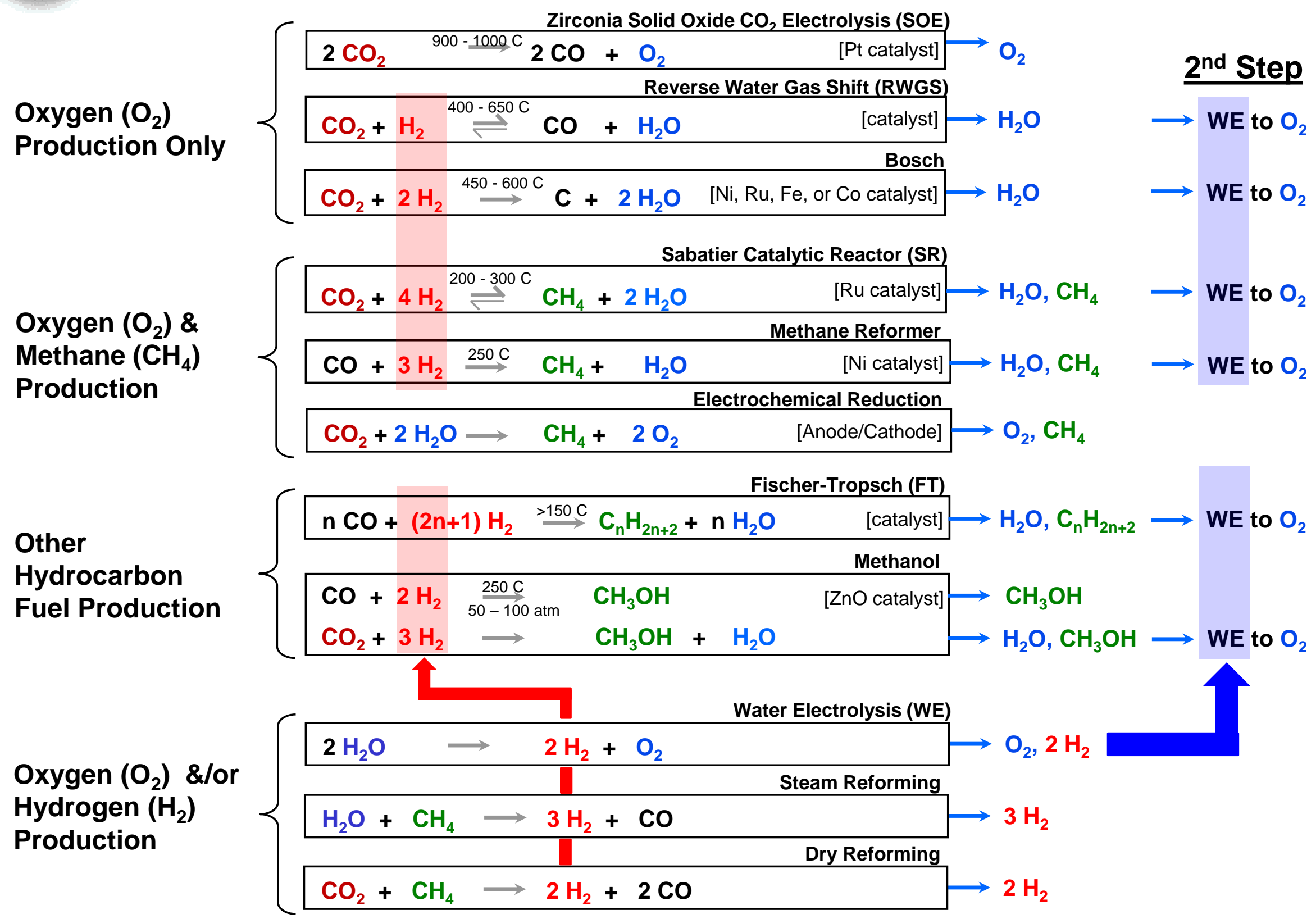




\section{Mars Design Reference Architecture (DRA) 5.0}




\section{Mars Resource \& ISRU Process Options}

- Four Options for Mars ISRU Ascent Propellant Production:

1. Make oxygen $\left(\mathrm{O}_{2}\right)$ from Mars atmosphere carbon dioxide $\left(\mathrm{CO}_{2}\right)$; Bring fuel from Earth

2. Make $\mathrm{O}_{2}$ and fuel/ $\mathrm{CH}_{4}$ from Mars atmosphere $\mathrm{CO}_{2}$ and hydrogen $\left(\mathrm{H}_{2}\right)$ from Earth

3. Make $\mathrm{O}_{2}$ and fuel/ $\mathrm{CH}_{4}$ from Mars atmosphere $\mathrm{CO}_{2}$ and water $\left(\mathrm{H}_{2} \mathrm{O}\right)$ from Mars soil

4. Make $\mathrm{O}_{2}$ and $\mathrm{H}_{2}$ from $\mathrm{H}_{2} \mathrm{O}$ in Mars soil

\begin{tabular}{|c|c|c|c|c|c|c|c|c|c|c|c|c|c|c|}
\hline & \multirow[b]{2}{*}{$\begin{array}{l}\text { ISRU Resource } \\
\text { Processing Options }\end{array}$} & \multirow[b]{2}{*}{ ISRU Products } & \multirow[b]{2}{*}{$\begin{array}{c}\text { Mars } \\
\text { Resource(s) }\end{array}$} & \multirow[b]{2}{*}{ Earth Supplied } & \multicolumn{10}{|c|}{ Process Subsystems/Options } \\
\hline & & & & & 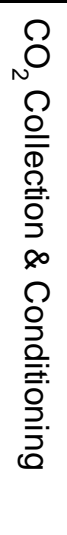 & 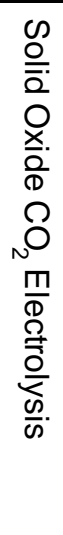 & 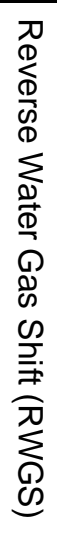 & 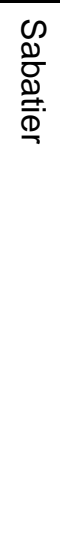 & 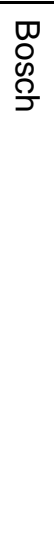 & 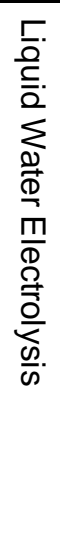 & 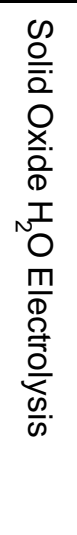 & 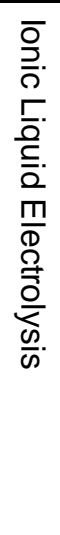 & 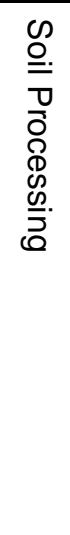 & 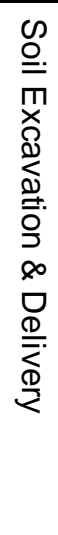 \\
\hline \multirow{5}{*}{ 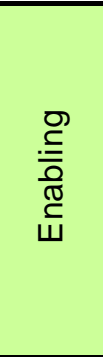 } & \multirow{5}{*}{ Atmosphere Processing } & \multirow{3}{*}{$\mathrm{O}_{2}$} & \multirow{5}{*}{$\mathrm{CO}_{2}$} & \multirow{3}{*}{$\mathrm{CH}_{4}(\sim 6600 \mathrm{~kg})^{2}$} & $\mathrm{X}$ & $X$ & & & & & & & & \\
\hline & & & & & $x$ & & $X$ & & & $x$ & & & & \\
\hline & & & & & $\mathrm{X}$ & & & & $\mathrm{X}$ & $x$ & & & & \\
\hline & & \multirow[t]{2}{*}{$\mathrm{O}_{2}, \mathrm{CH}_{4}, \mathrm{H}_{2} \mathrm{O}$} & & \multirow[t]{2}{*}{$\mathrm{H}_{2}^{*}(\sim 2000 \mathrm{~kg})$} & $\mathrm{X}$ & & $\mathrm{X}$ & $\mathrm{X}$ & & $\mathrm{X}$ & & & & \\
\hline & & & & & $x$ & & & & & & & $x$ & & \\
\hline \multirow{3}{*}{ 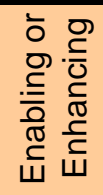 } & Soil Processing & $\mathrm{O}_{2}, \mathrm{CH}_{4}, \mathrm{H}_{2} \mathrm{O}$ & $\mathrm{H}_{2} \mathrm{O}$ & $\mathrm{CH}_{4}{ }^{* *}(\sim 6600 \mathrm{~kg})$ & & & & & & $x$ & & & $x$ & $x$ \\
\hline & \multirow{2}{*}{$\begin{array}{l}\text { Atmosphere \& Soil } \\
\text { Processing }\end{array}$} & \multirow{2}{*}{$\mathrm{O}_{2}, \mathrm{CH}_{4}, \mathrm{H}_{2} \mathrm{O}$} & \multirow{2}{*}{$\mathrm{CO}_{2} \& \mathrm{H}_{2} \mathrm{O}$} & \multirow[t]{2}{*}{3} & $\mathrm{X}$ & & & $x$ & & $x$ & & & $x$ & $x$ \\
\hline & & & & & $X$ & & & $X$ & & & $X$ & & $x$ & $x$ \\
\hline
\end{tabular}




\section{Mars Water Form \& Distribution}

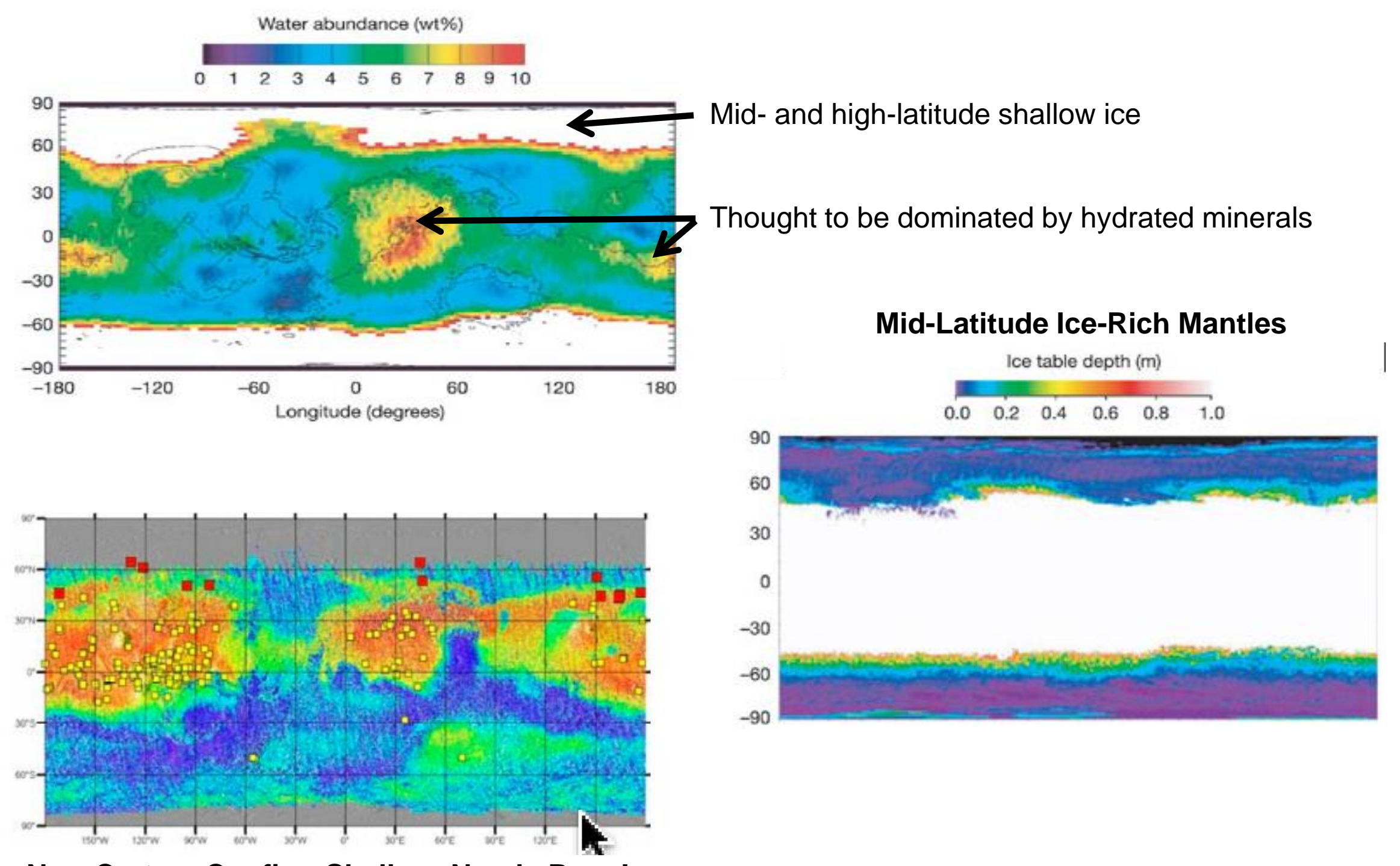

New Craters Confirm Shallow, Nearly Pure Ice

- Newly formed craters exposing water ice (red) are a subset of all new craters (yellow). Background color is TES dust index. (Adapted from Byrne et al. (2011) Science) 


\section{Water Abundance and Mars Altitude}

Water Equivalent

Hydrogen Abundance
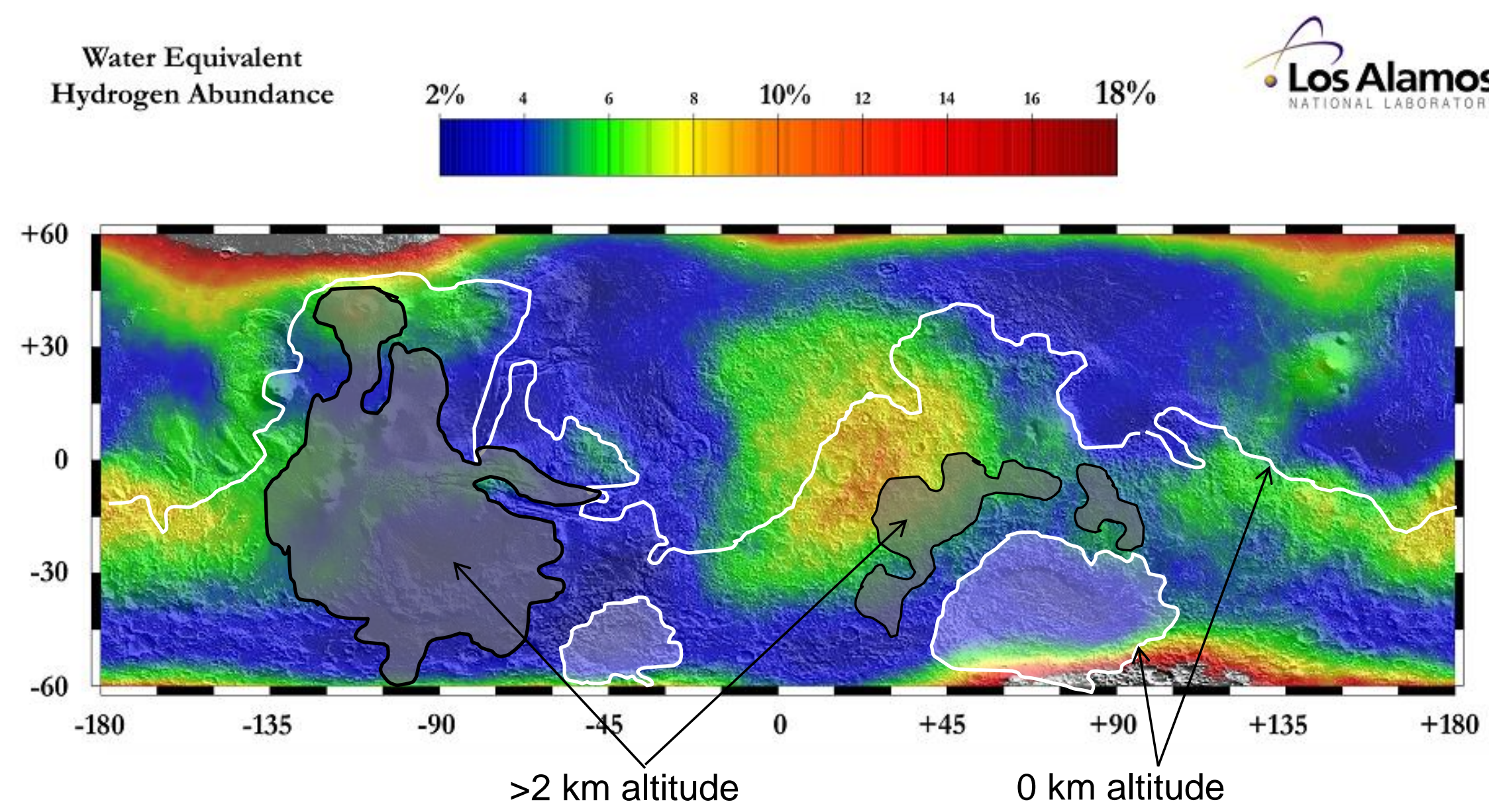

Water resources between $5-8 \%$ near the surface is highly possible for ISRU 


\section{Mars Design Reference Architecture (DRA) 5.0}

- Evaluate Atmosphere Processing Only

- Re-evaluate past technologies and system concepts and perform internal trade to determine best approach for following three ISRU applications:

- Propellant production only

- EVA and Life support backup only

$>$ Combined propellant and EVA/life support backup

- Evaluate $\mathrm{H}_{2}$ delivery vs fuel delivery from Earth on Lander volume and mass. Use habitat lander as basis of 'goodness'

- Evaluate Feasibility and Size of Mars Soil/Water Processing System

- Make $\mathrm{O}_{2}$ and $\mathrm{CH}_{4}$ with Mars water and atmospheric $\mathrm{CO}_{2}$

- Define Mars soil and water properties at possible exploration sites of interest

- Coordinate with Science community

- ISRU study assumed 3-8\% global concentration and only top few centimeters was excavated/processed due to Planetary Protection concerns

- Evaluate ISRU on Mars Architecture above simple impact on ascent vehicle and surface systems

- Evaluate both circular and highly elliptical orbit impact of ISRU-fuel ascent vehicle on Architecture

- ISRU Production Requirements

\begin{tabular}{|c|c|c|c|c|c|}
\hline \multirow[b]{2}{*}{ ISRU to Close Crew \& EVA Consumables } & \multicolumn{5}{|c|}{ JuU days - Gevo } \\
\hline & $\mathrm{O}_{2}$ & Water & $\mathrm{N}_{2} / \mathrm{Ar}$ & Earth $\mathrm{H}_{2}$ & \\
\hline - Mars Atm. Processing only & 1906 & & 133 & 399 & $\begin{array}{l}\text { - Closes wa } \\
\text { brought fro }\end{array}$ \\
\hline - Mars Soil Processing only & & $\begin{array}{l}2146 \\
3586 \\
\end{array}$ & $\begin{array}{l}133 \\
133 \\
\end{array}$ & 160 & $\begin{array}{l}\text { - Closes wa } \\
\text { - Closes wa }\end{array}$ \\
\hline - Mars Atm. \& Soil Processing & 1281 & 2146 & 133 & & - Closes wa \\
\hline ISRU for All Consumables & $\mathrm{O}_{2}$ & Water & $\mathrm{N}_{2} / \mathrm{Ar}$ & Earth $\mathrm{H}_{2}$ & Earth $\mathrm{CH}_{4}$ \\
\hline $\begin{array}{l}\mathrm{O}_{2} \text { Only for Propulsion w/ Earth } \mathrm{CH}_{4} \\
\mathrm{O}_{2} / \mathrm{CH}_{4} \text { Propellant for Propulsion w/ Earth } \mathrm{H}_{2} \mathrm{O} \\
\mathrm{O}_{2} / \mathrm{CH}_{4} \text { Propellant for Propulsion w/ Mars } \mathrm{H}_{2} \mathrm{O}\end{array}$ & $\begin{array}{l}24891 \\
24891 \\
24266 \\
\end{array}$ & 16788 & $\begin{array}{l}133 \\
133 \\
133 \\
\end{array}$ & $\begin{array}{c}399 \\
2069\end{array}$ & 6567 \\
\hline
\end{tabular}



Ground Rules

\section{- Soil}

- Water content in Mars soil $3 \%$ by weight; $1000 \mathrm{~kg} / \mathrm{m}^{3}$; homogeneous distribution (no dry layer at top)

- Also examined impact of $8 \%$ water by weight and $2000 \mathrm{~kg} / \mathrm{m}^{3}$

$-6 \%$ sulfur in soil by weight

\section{- Soil Excavation}

- Excavation hauler vehicles; level ground

- $8 \mathrm{hr}$ case: assume each excavator can provide the needed 4 batches; continuous operation over the $8 \mathrm{hrs}$; recharge at night

- $24 \mathrm{hr}$ case: assume each excavator can provide the needed 6 batches; operate for $12 \mathrm{hrs}$ and recharge for 12 hrs each day

- Distance traveled: $500 \mathrm{~m}$ from site to plant (loaded); $500 \mathrm{~m}$ from plant to dump site (loaded); $500 \mathrm{~m}$ from dump site to excavation site (unloaded)

- Speed: $0.5 \mathrm{~m} / \mathrm{s}$ during hauling

- Depth per cut: $4 \mathrm{~cm}$; Total depth: $8 \mathrm{~cm}$

- Dump time to inlet hopper $=5 \mathrm{~min}$;; Time to fill dump from outlet hopper $=5 \mathrm{~min}$.

- Excavation concept assumed: Front-end loader

- Hauler concept assumed: Dump bin

- Soil Processing

- Water extraction system includes: hopper, auger, extraction reactor (fluidized bed, $\mathrm{H}_{2}$ reduction reactor model), gas clean-up (packed bed, desulfurization model), and water condenser

- Processing energy provided by separate electrical power system

- Soil processing batch time: 2 hrs

- Inlet and outlet hoper sized to hold 2 days worth of Mars soil for processing for ECLSS cases and 1 day for propellant production

- Heat up power is estimated using basalt model for lunar ISRU

- Processing temperature - heat from soil from input 300K (27C) to processing 600K (327C) 


\section{Mars Human Exploration DRA 5.0 ISRU vs Non-ISRU Ascent Results}

- Lowest Power/Volume: Process atmospheric $\mathrm{CO}_{2}$ into $\mathrm{O}_{2}$; Bring methane $\left(\mathrm{CH}_{4}\right)$ from Earth

- Lowest Mass: Process atmospheric $\mathrm{CO}_{2}$ with Soil processing for $\mathrm{H}_{2} \mathrm{O}$ into $\mathrm{O}_{2}$ and $\mathrm{CH}_{4}$

- Study Results

$>$ Atmosphere processing into $\mathrm{O}_{2}$ baselined: Lowest Risk

$>$ Continue evaluation of water on Mars and soil processing to reduce risk

\begin{tabular}{|c|c|c|}
\hline \multicolumn{3}{|c|}{ DAV Mass (no ISRU) } \\
\hline Ascent Stg 2 $^{\text {Ascent Stg 1 }}$ & 18,540 & $\mathrm{~kg}$ \\
\hline Ascent $^{\dagger}$ & 27,902 & $\mathrm{~kg}$ \\
\hline Minimal Habitat $^{\dagger}$ & 5687 & $\mathrm{~kg}$ \\
\hline Descent stage $^{\star}$ & 27,300 & $\mathrm{~kg}$ \\
\hline & & \\
\hline Total & 79,428 & $\mathrm{~kg}$ \\
\hline
\end{tabular}

* Wet mass; does not include EDL System

† Packaging not currently considered

\begin{tabular}{|c|c|c|}
\hline \multicolumn{3}{|c|}{ DAV Mass (w/O2 ISRU) } \\
\hline Ascent Stg 2 & 9,330 & $\mathrm{~kg}(\mathrm{CH} 4)$ \\
\hline Ascent Stg 1 & 12,156 & $\mathrm{~kg}(\mathrm{CH} 4)$ \\
\hline ISRU and Power $^{\dagger}$ & 11280 & $\mathrm{~kg}$ \\
\hline Descent stage* & 21,297 & $\mathrm{~kg}$ \\
\hline Total & 54,062 & $\mathrm{~kg}$ \\
\hline
\end{tabular}

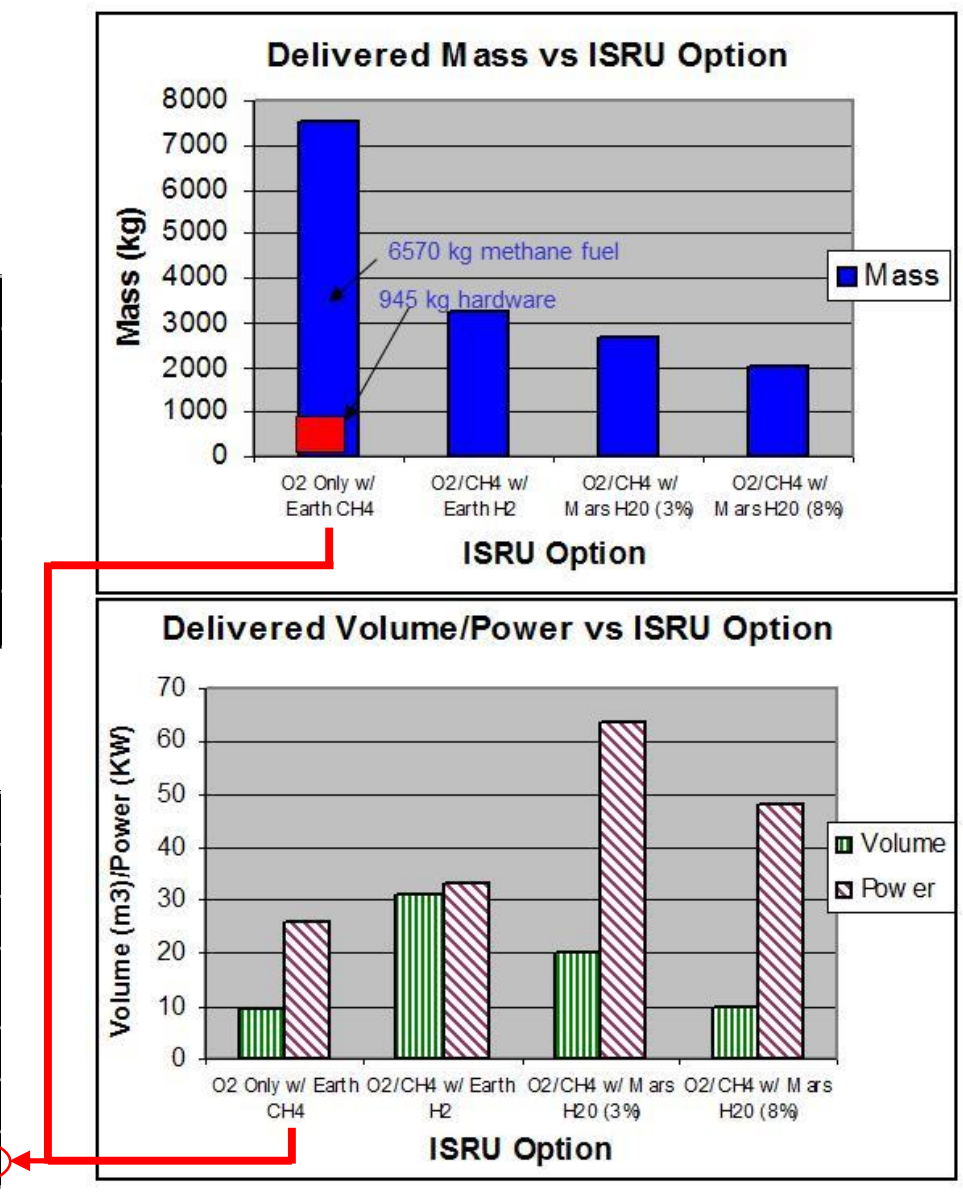

$>25 \mathrm{MT}$ savings $(>30 \%)$ 


\section{Mars Collaborative Study}




\section{Mars Collaborative Study - 2013}

Purpose

- Evaluate Mars ISRU technology and system options for propellant production on Mars for a sample return mission

- Oxygen from Mars atmosphere (carbon dioxide)

- Oxygen and Fuel from Mars atmospheric carbon dioxide and water in soil

- Examine impact on scale to human mission needs on technology and system selection

- Determine acceptable scale for risk reduction of human mission

- Examine whether technologies can be scaled down to Mars 2020 precursor

- Examine state-of-the-art (SOA) of Mars ISRU technologies and potential development cost/risk

- Look for synergism with fuel cell power, life support, and propulsion technology development and system applications

- Look ahead to potential advancements in 5 to 10 years in SOA

\section{Approach}

- Decouple ISRU plant trade from mission by focusing on production rates

- Begin evaluation at major subsystem level

- Start with realistic schematics with components and sensor locations identified for major subsystems

- Oxygen $\left(\mathrm{O}_{2}\right)$ Production from Atmosphere Resources

- Oxygen/Methane $\left(\mathrm{O}_{2} / \mathrm{CH}_{4}\right)$ Production from Atmosphere/Soil Resources

$>$ Subsystem down-selection decisions effected by complete system performance

- Need Power and Cryogenic Fluid System support to understand 'system' implications

- Need to ensure decisions on interface temp/pressure is consistent at system level 


\section{Mars ISRU Trade Tree}

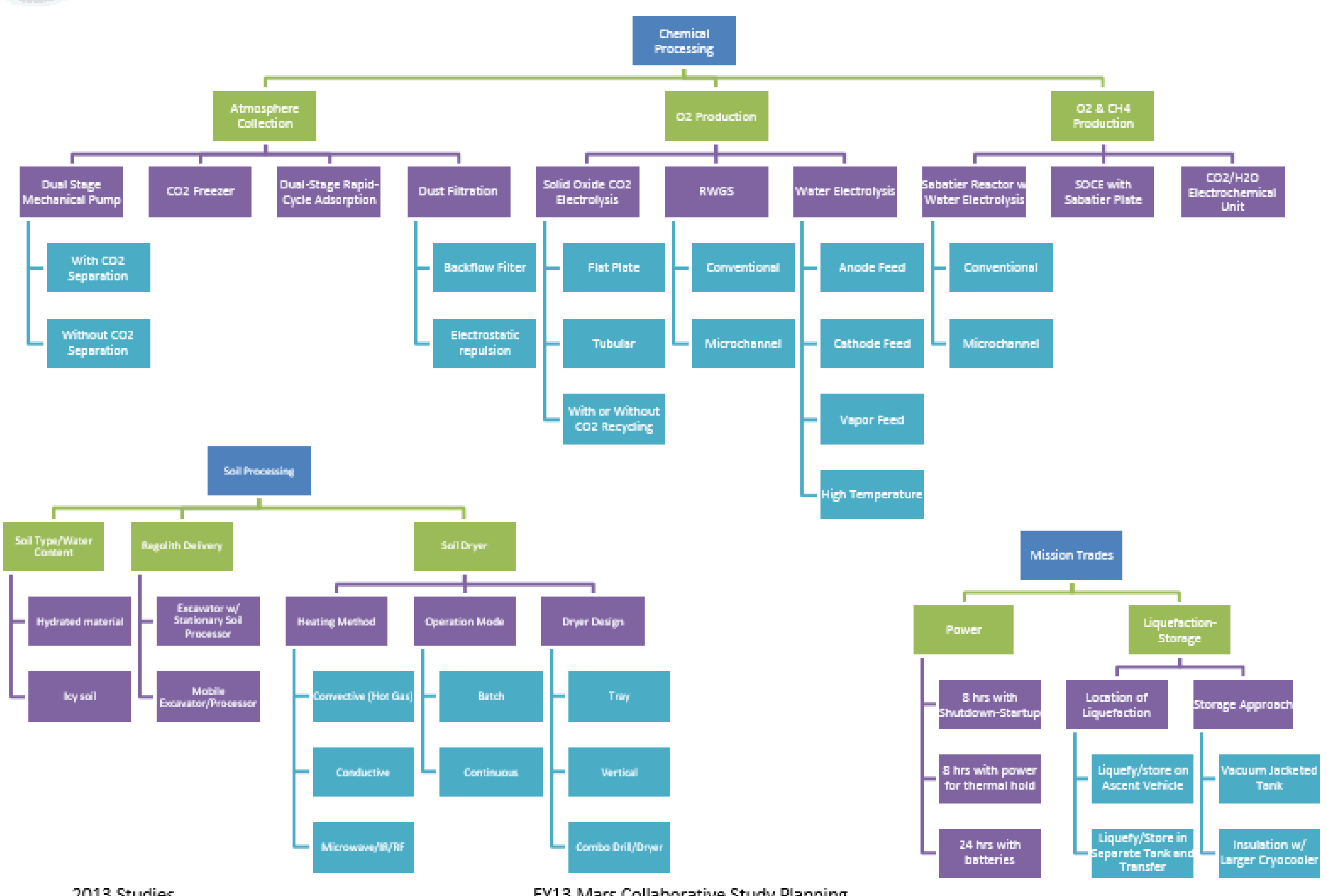

2013 Studies

FY13 Mars Collaborative Study Planning 


\section{Mars Collaborative ISRU Study Results (1)}

\begin{tabular}{|c|c|c|c|c|c|c|}
\hline \multirow[t]{2}{*}{ ISRU Process } & \multicolumn{2}{|c|}{$0.15 \mathrm{~kg} / \mathrm{hr}$} & \multicolumn{2}{|c|}{$0.35 \mathrm{~kg} / \mathrm{hr}$} & \multicolumn{2}{|c|}{$0.75 \mathrm{~kg} / \mathrm{hr}$} \\
\hline & $\mathrm{kg}$ & W & $\mathrm{kg}$ & W & $\mathrm{kg}$ & W \\
\hline Solid Oxide $\mathrm{CO}_{2}$ Electrolysis & 55 & 1444 & 126 & 3295 & 264 & 6976 \\
\hline Reverse Water Gas Shift w/Water Electrolysis & 57 & 1328 & 101 & 3084 & 189 & 6770 \\
\hline $\begin{array}{l}\text { Solid Oxide } \mathrm{CO}_{2} / \mathrm{H}_{2} \mathrm{O} \text { Electrolysis w/Sabatier \& } \\
\text { Mars Soil }\end{array}$ & 56 & 1631 & 90 & 3788 & 128 & 8110 \\
\hline Sabatier w/Water Electrolysis \& Mars Soil & 64 & 1744 & 95 & 3793 & 149 & 7775 \\
\hline
\end{tabular}

Note:

1. Mass of rover for soil excavation is not shown since it uses the sample fetch rover once the samples have been collected

2. Liquefaction mass and power not included since they will be similar for all options with the same production rate

\begin{tabular}{|c|c|c|c|c|c|c|c|c|}
\hline $\begin{array}{l}\text { ISRU Subystem/System } \\
\text { Attributes }\end{array}$ & 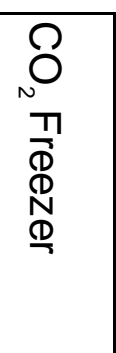 & 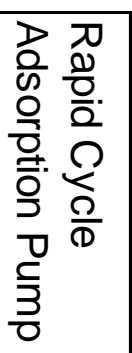 & $\begin{array}{l}\infty \\
\text { O } \\
\text { m }\end{array}$ & 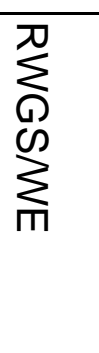 & 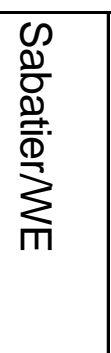 & 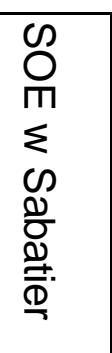 & 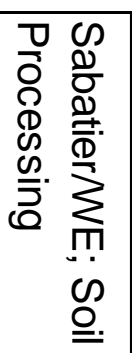 & 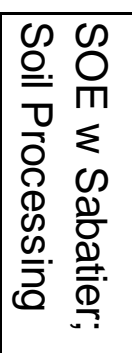 \\
\hline Complexity & G & $\mathrm{M}$ & G & $P$ & G & G & $\mathrm{P}$ & $\mathrm{P}$ \\
\hline Number of active components & 6 & 15 & 8 & 20 & 11 & 10 & 21 & 20 \\
\hline Rapid Startup/Shutdown & $\mathrm{M}$ & $\mathrm{G}$ & $\mathrm{P}$ & $\mathrm{G}$ & $\mathrm{G}$ & $P$ & $\mathrm{G}$ & $P$ \\
\hline Commonality with Life Support & $\mathrm{M}$ & $\mathrm{G}$ & $P$ & $\mathrm{M}$ & $\mathrm{G}$ & $\mathrm{M}$ & $\mathrm{G}$ & $\mathrm{M}$ \\
\hline Commonality with Fuel Cell Power & & & G & $\mathrm{M}$ & $\mathrm{M}$ & & & \\
\hline
\end{tabular}

Rankings are relative: $G=$ Good, $P=$ Poor, $M=$ Medium 


\section{Mars Collaborative ISRU Study Results (2)}

- Mars Atmosphere $\mathrm{CO}_{2}$ Collection

- Microchannel Rapid-Cycle $\mathrm{CO}_{2}$ Collection technology preferred over $\mathrm{CO}_{2}$ Freezer

- $\mathrm{CO}_{2}$ Freezer more likely scalable down to Mars 2020 mission

- $\mathrm{O}_{2}$ Production from Mars Atmosphere

- Both Solid Oxide $\mathrm{CO}_{2}$ Electrolysis (SOCE) and Microchannel Reverse Water Gas Shift with Water Electrolysis (RWGS/WE) have comparable mass and power

- SOCE is slightly lighter and simpler but may be more risky. Less synergistic with life support but more synergistic with solid oxide fuel cell; Best packaging for Mars 2020 ISRU demonstration

- All microchannel design $\left(\mathrm{CO}_{2}\right.$ collection, RWGS reactor, water vapor separation) may be best for packaging and scalability to human mission; Also not as effected by day/night operation cycle from solar power.

- $\mathrm{O}_{2}$ and $\mathrm{CH}_{4}$ Production from Mars Atmosphere and Soil

- Both Solid Oxide $\mathrm{CO}_{2}$ Electrolysis (SOCE) with Sabatier and Microchannel Sabatier with Water Electrolysis have comparable mass and power

- Mars soil excavator or processor appears to be able to fit on sample cache rover; power system will need to be supplemented

- Similar pros/cons for SOCE vs microchannel as $\mathrm{O}_{2}$ Production only

- Ionic liquid concept shows tremendous promise but is still too low in TRL to select

- Key Findings on ISRU Concept Discriminators

- When considering only mass and power of the ISRU system concept, atmosphere only vs atmosphere/soil are comparable to each other

- Advanced technologies such as microchannel reactors, heat exchangers, water/gas separators, and carbon dioxide adsorption pumps provide significant mass/volume improvement over conventional technologies as production rates increase

- Oxygen only production from the Mars atmosphere is less synergistic with life support systems than oxygen/fuel production since these ISRU processes produce carbon monoxide 


\section{Mars ISRU Demo Payload for Supersonic Retro Propulsion (SRP) Mission}




\section{Mars ISRU Demo Payload for Supersonic Retro Propulsion (SRP) Mission}

- Assumptions for ISRU payload definition:

- Mass of (TBR) 2MT maximum

- Deck height for payload 1 meter height above surface; horizontal landing

- CG roughly centered (soft requirement)

- Cylindrical payload volume: 2 m dia. X 4 m long

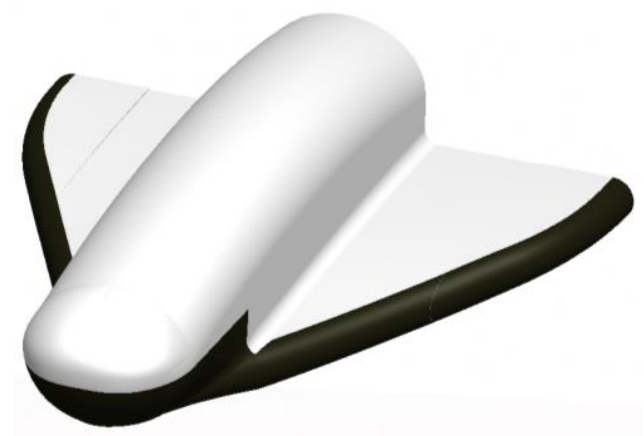

- ISRU payload study purpose:

a. Determine highest production rate/scale possible within payload mass/volume limits

- Define maximum amount of power to ISRU payload - use solar arrays

- Define/utilize remaining payload for ISRU and storage.

b. Provide 3-D packaging concept for atmosphere processing and soil processing demonstrations

c. Determine payload applicability to human scale mission

- ISRU Demo Payload Options:

- Atmosphere processing for oxygen $\left(\mathrm{O}_{2}\right)$ production alone with $\mathrm{O}_{2}$ storage

- Soil processing for water $\left(\mathrm{H}_{2} \mathrm{O}\right)$ with $\mathrm{O}_{2}$ storage

- Combined Atmosphere/Soil Processing for $\mathrm{O}_{2}$ and Methane $\left(\mathrm{CH}_{4}\right)$ production and storage

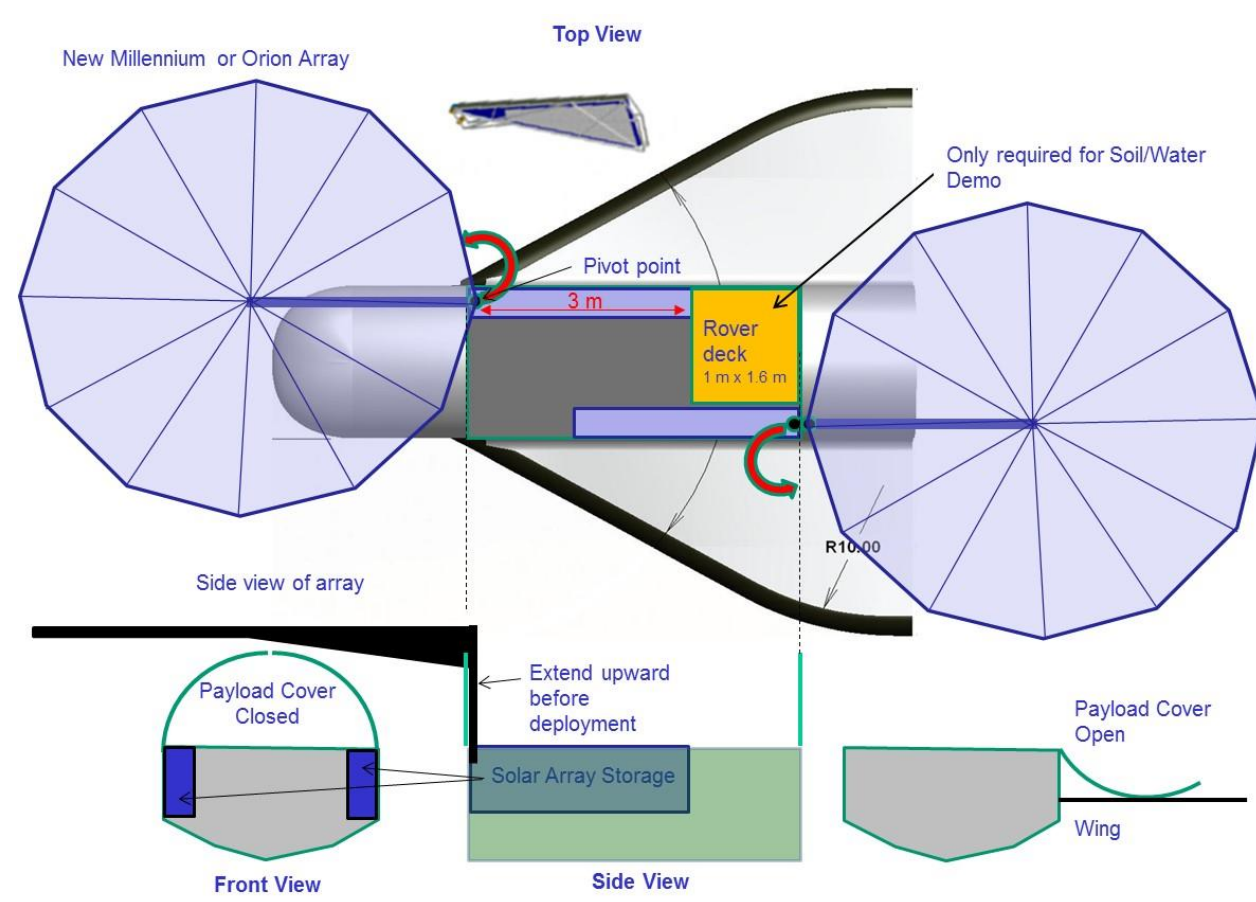




\section{Mars ISRU SRP Payload Study Analysis Overview}

- ISRU Demo mass, power, and volume are first order estimates

- All items required for successful operation included in payload. No sharing of SRP subsystems/hardware

- Technologies \& processes were selected to bound the wide scope of possible process configurations.

- No day/night operation (startup/shutdown impacts) or power impacts analyzed. Just assumed constant production rate for 8 hours per Mars day (sol).

- Components requiring heat rejection were identified for start of thermal management/packaging

- Packaging based on subsystem connectivity

- Center of Gravity (c.g) management not considered in ISRU demo packaging at this time.

- Notional landing location/latitude and time of year selected that was not based on an actual mission concept (not available)

- 15 deg. north latitude selected. Considered reasonable location for landing (low MOLA)

- Landing at Ls 180 maximizes solar power generation capability at landing location; assume landing 50 days prior for 100 day mission

- Power/packaging evaluation performed for notional landing location

- Packaging of 5.5 to $6 \mathrm{~m}$ diameter array possible based on notional payload bay and use of ATK UtraFlex solar array design parameters

- Equates to rough estimate of 6.5 to $7.5 \mathrm{KWe}$ power generation possible

- Assumed 6.5 KWe for 8 hours per sol as reasonably conservative estimate 


\section{Mars ISRU Demo SRP Payload Study Results}

\section{Mars Atm ISRU Demo}

\begin{tabular}{|l|c|c|}
\hline $\mathrm{O}_{2}$ Production rate: $0.45 \mathrm{~kg} / \mathrm{hr}$ & Mass $(\mathrm{kg})$ & Power $(\mathrm{KW})$ \\
\hline Filtration & 1.23 & 0.00025 \\
\hline $\mathrm{CO}_{2}$ Collection/Freezer & 173 & 2.23 \\
\hline SOE Processor & 5.6 & 3.7 \\
\hline SOE Recirculation system & 34.6 & 0.187 \\
\hline $\mathrm{O}_{2}$ Liquefaction and Storage & 70 & 0.6 \\
\hline Secondary Structure (15\%) & 42.7 & \\
\hline Solar Arrays (2) & 45 & \\
\hline Power conditioning/batteries & TBD & TBD \\
\hline Thermal Management/Radiators & TBD & TBD \\
\hline Total & 372.1 & 6.72
\end{tabular}

Mars Soil ISRU Demo

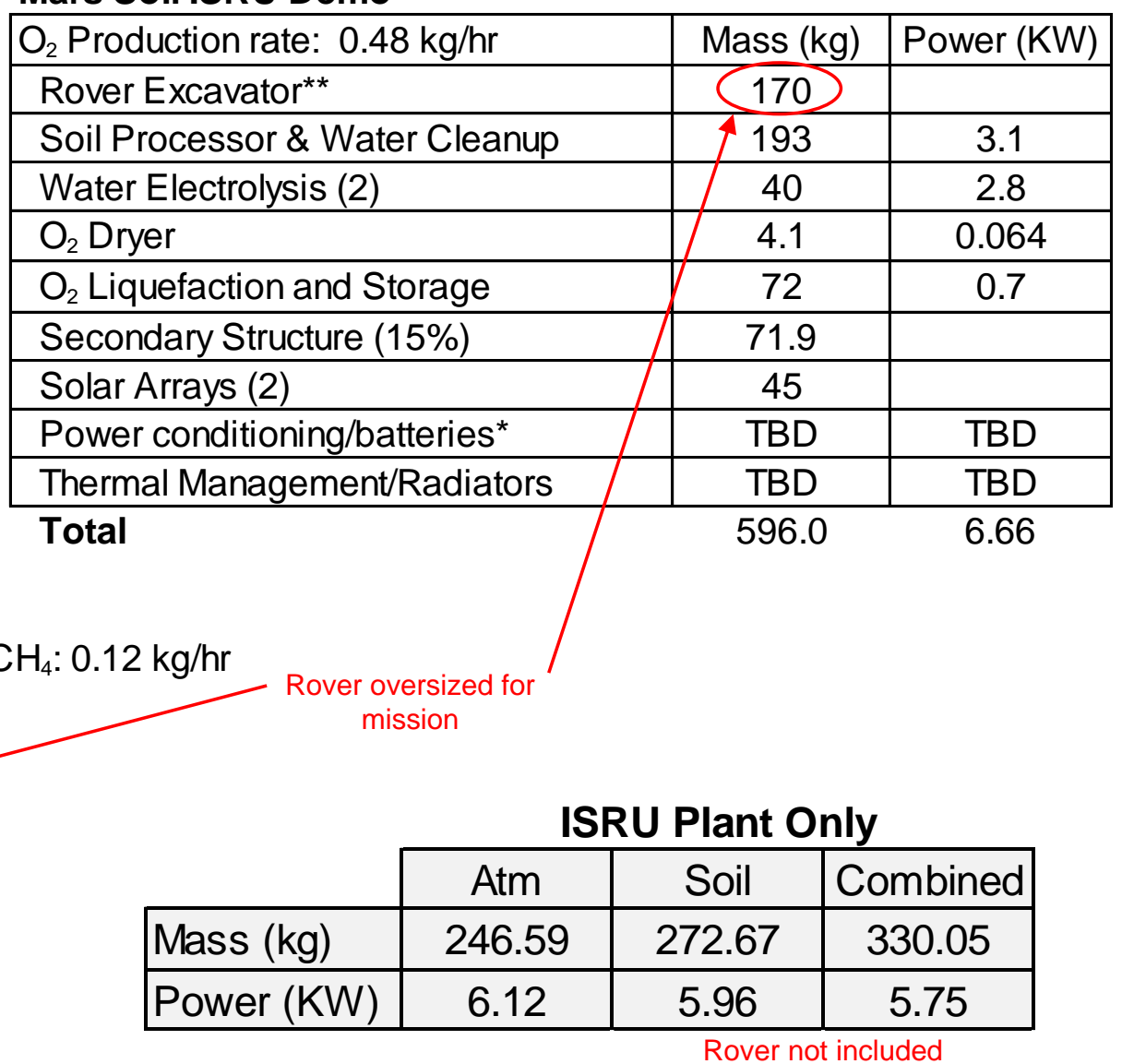

Human mission would include 3 units (each slightly scaled up)

\section{Combined Atm/Soil ISRU Demo}

\begin{tabular}{|c|c|c|}
\hline $\mathrm{O}_{2}$ Production rate: $0.48 \mathrm{~kg} / \mathrm{hr}$; & Mass (kg) & Power (KW) \\
\hline Filtration & 1.3 & 0.00025 \\
\hline $\mathrm{CO}_{2}$ Collection/Freezer & 43 & 0.574 \\
\hline Sabatier Microchannel Reactor & 1 & 0.082 \\
\hline Rover Excavator ${ }^{\star \star}$ & 170 & \\
\hline Soil Processor \& Water Separation & 193 & 1.7 \\
\hline Water Capture/Temp Storage & 3.7 & 0.5 \\
\hline Water Electrolysis (2) & 40 & 2.8 \\
\hline $\mathrm{O}_{2}$ and $\mathrm{CH}_{4}$ Dryers & 5 & 0.098 \\
\hline $\mathrm{O}_{2}$ Liquefaction and Storage & 72 & 0.7 \\
\hline $\mathrm{CH}_{4}$ Liquefaction and Storage & 58 & 0.42 \\
\hline Secondary Structure (15\%) & 88.1 & \\
\hline Solar Arrays (2) & 45 & \\
\hline Power conditioning/batteries* & TBD & TBD \\
\hline Thermal Management/Radiators & TBD & TBD \\
\hline Total & 720.1 & 6.9 \\
\hline
\end{tabular}

G. Sanders, (281) 483-9066, gerald.b.sanders1@jsc.nasa.gov 
Region 1: <300 C

- $40-50 \%$ of the water released

- Minimal release of $\mathrm{HCl}$ or $\mathrm{H}_{2} \mathrm{~S}$

\section{Region 2: $<450 \mathrm{C}$}

- $>80 \%$ of the water released

- $\mathrm{CO}_{2}$ and $\mathrm{O}_{2}$ released from decomposition of perchlorates and oxidation of organic material

- Some release of $\mathrm{HCl}$ or $\mathrm{H}_{2} \mathrm{~S}$, but before significant amounts are release at higher temperatures

\section{Predicted Volatile Release Based on Lab Experiments} $\underline{\mathrm{CO}}_{2}$ released by

1. Absorbed atmosphere $<200 \mathrm{C}$

2. Oxidation of organic material $>200 \mathrm{C}$

3. Thermal decomposition of carbonates $>450 \mathrm{C}$

$\underline{\mathrm{O}}_{2}$ released by

1. Dehydroxylation of clays $<350 \mathrm{C}$

2. Decomposition of non-metal and metal oxides $>500 \mathrm{C}$

$\underline{\mathrm{CH}}_{3} \underline{\mathrm{Cl} \text { and } \mathrm{CH}_{2}} \underline{\mathrm{Cl}}_{2}$ released by

1. Decomposition of $\mathrm{Mg}\left(\mathrm{ClO}_{4}\right)_{2}$ perchlorate $>200 \mathrm{C}$

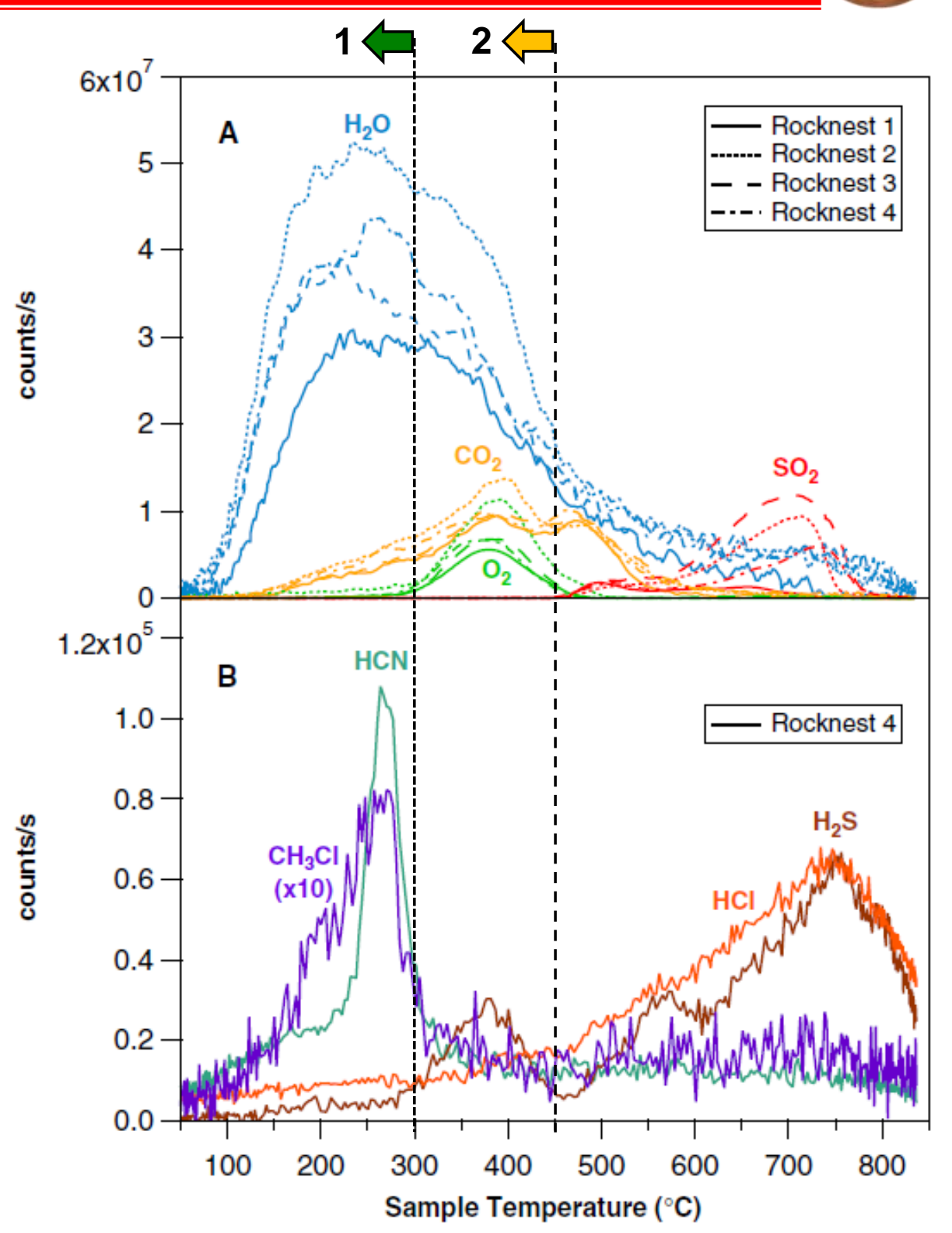




\section{Mars ISRU State of the Art}




\section{Mars ISRU Propellant Production}

Needs

- Propellant production for human mission ascent (Mars DRA 5.0)

- For $\mathrm{O}_{2}$ only: 2.2 to $3.5 \mathrm{~kg} / \mathrm{hr} \mathrm{O}_{2} ; 480$ days or 300 days

- For $\mathrm{O}_{2} / \mathrm{CH}_{4}$ :

- 0.55 to $0.88 \mathrm{~kg} / \mathrm{hr} \mathrm{CH}_{4}$

- 1.2 to $2.0 \mathrm{~kg} / \mathrm{hr} \mathrm{H} \mathrm{H}_{2} \mathrm{O}$; (41 to $66 \mathrm{~kg} / \mathrm{hr}$ soil @ 3\% H2O by mass)

- Propellant production for Mars Sample Return

- 0.35 to $0.5 \mathrm{~kg} / \mathrm{hr} \mathrm{O}_{2} ; 420$ to 500 days (multiple studies)

- 0.75 to $1.5 \mathrm{~kg} / \mathrm{hr} \mathrm{O} 2 ; 35$ or 137 days (Mars Collaborative Study 4-2012)

- Propellant production for Mars ISRU Demo

- $0.02 \mathrm{~kg} / \mathrm{hr} \mathrm{O}_{2} ; \quad 50$ operations (Mars $2020 \mathrm{AO}$ requirement)

- $0.00004 \mathrm{~kg} / \mathrm{hr} \mathrm{O}_{2} ; 10$ operations (MIP demo on Mars 2001 Surveyor)

Demonstrated

- Mars ISRU Testbeds (late '90s early '00s):

- LMA/JSC Sabatier/Water Electrolysis: $0.02 \mathrm{~kg} / \mathrm{hr} \mathrm{O}_{2} ; 0.01 \mathrm{~kg} / \mathrm{hr} \mathrm{CH}_{4}$

- KSC RWGS/Water Electrolysis $0.087 \mathrm{~kg} / \mathrm{hr} \mathrm{O}$

- Pioneer Astronautics (SWE \& RWGS): $0.02 \mathrm{~kg} / \mathrm{hr} \mathrm{O} \mathrm{O}_{2} ; 0.01 \mathrm{~kg} / \mathrm{hr} \mathrm{CH}_{4}$ (IMISPPS): $0.031 \mathrm{~kg} / \mathrm{hr} \mathrm{O}, 0.0088 \mathrm{~kg} / \mathrm{hr}^{4} \mathrm{CH}_{4}$

- Atmosphere Processing: MARCO POLO (Individual subsystems)

- $\mathrm{CO}_{2}$ Collection: $0.088 \mathrm{~kg} / \mathrm{hr} \mathrm{CO}_{2}$

- $\mathrm{CO}_{2}$ Processing: $0.066 \mathrm{~kg} / \mathrm{hr}$ of $\mathrm{O}_{2} ; 0.033 \mathrm{~kg} / \mathrm{hr}$ of $\mathrm{CH}_{4} ; 0.071 \mathrm{~kg} / \mathrm{hr}$ of $\mathrm{H}_{2} \mathrm{O}$

- Water Processing: $0.52 \mathrm{~kg} / \mathrm{hr} \mathrm{H}_{2} \mathrm{O} ; 0.46 \mathrm{~kg} / \mathrm{hr} \mathrm{O}_{2}$

- Soil Processing:

- Lunar $\mathrm{H}_{2}$ Reduction - ROxygen Reactor: 5 to $10 \mathrm{~kg} / \mathrm{hr}$ soil:

- Lunar $\mathrm{H}_{2}$ Reduction - PILOT Reactor: 4.5 to $6 \mathrm{~kg} / \mathrm{hr}$ soil:

- Mars Soil Auger - MISME: $\quad 0.18$ to $0.2 \mathrm{~kg} / \mathrm{hr}$ soil

- Mars Soil Reactor-Pioneer Ast. Hot $\mathrm{CO}_{2} 4 \mathrm{~kg} / \mathrm{hr}$ soil per batch 

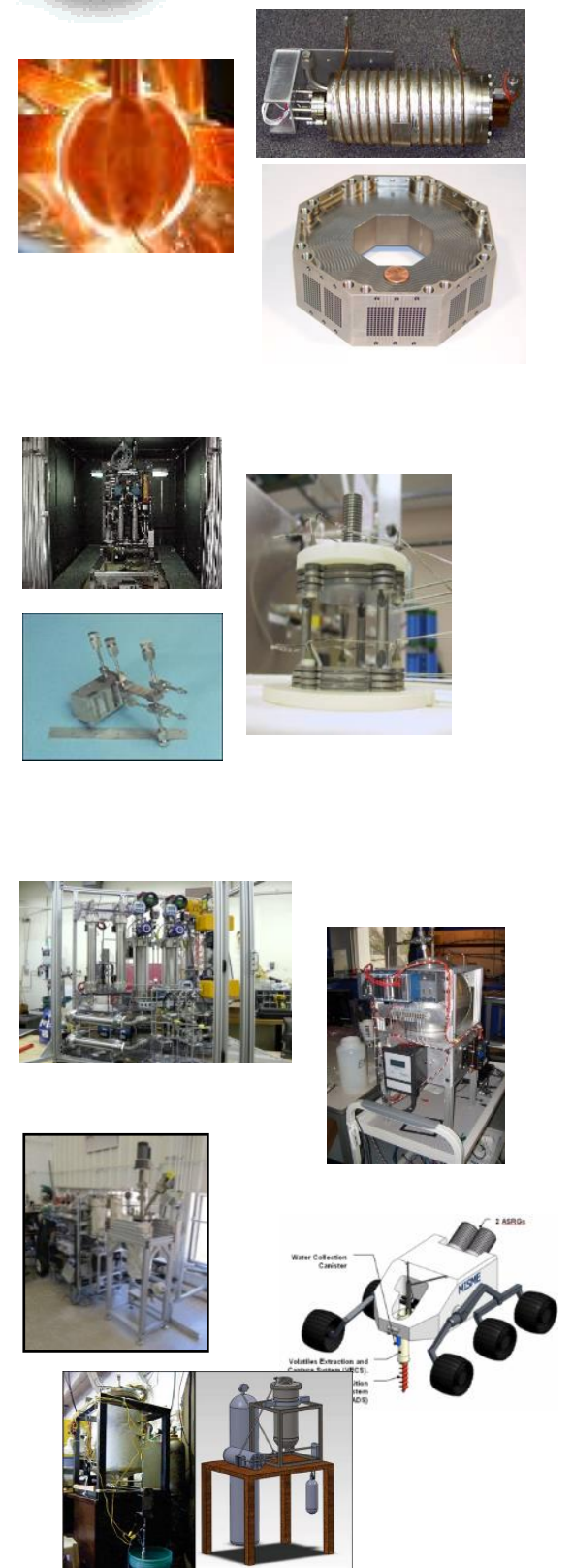

G. Sanders, (281) 483-9066, gerald.b.sanders1@jsc.nasa.gov

$\mathrm{CO}_{2}$ Collection \& Separation

- Mars atmosphere adsorption pump (JPL, ARC, LMA, JSC)

- Microchannel adsorption pump (PNNL, SBIR)

- Mars atmosphere solidification pump (LMA, SBIR, NASA)

$\mathrm{CO}_{2}$ Processing

- $\mathrm{CO}_{2}$ electrolysis \& low pressure dissociation (NASA, Univ. of Arizona, Old Dominion, Industry, SBIRs)

- Reverse Water Gas Shift (KSC, PNNL, SBIRs)

- Sabatier reactors (NASA, Industry, SBIRs)

- Methane reformer (JPL, SBIRs)

- Hydrocarbon fuel reactors - methanol, toluene, ethylene, etc. (SBIRs)

- Microchannel reactors/heat exchangers (PNNL, SBIRs)

\section{Water Processing}

- Water electrolysis/decomposition (NASA, Industry, SBIRs)

- Water cleanup for lunar soil processing (KSC, SBIRs)

- Water vapor/gas cleanup for lunar soil processing (NASA, SBIRs)

\section{Soil Processing}

- $\mathrm{H}_{2}$ Reduction of regolith reactors (NASA, LMA)

- Lunar volatile extraction (NASA, Industry)

- Mars soil processing (JSC, SBIRs) 


\section{Past/Recent Mars ISRU System Development}

Mars Atmosphere Processing

- $1^{\text {st }}$ Gen Sabatier/Water Electrolysis (SWE) breadboard under ambient \& Mars environment testing (NASA, Lockheed Martin)

- $1^{\text {st }}$ Generation Reverse Water Gas Shift with and w/o Fuel production (NASA, Pioneer Astronautics)

- $2^{\text {nd }}$ Gen MARCO POLO atmosphere processing (JSC, KSC)

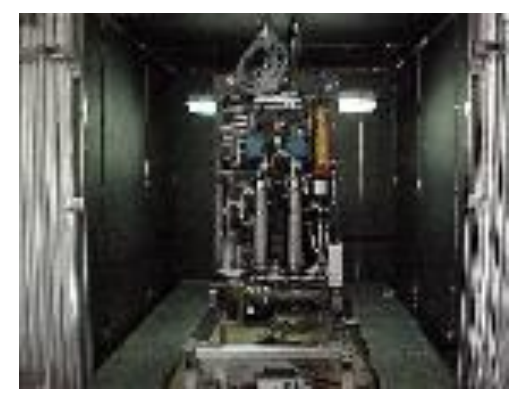

Sabatier/Water Electrolysis w/ $\mathrm{CO}_{2}$ Absorption (LMA \& JSC) [Tested under simulate Mars surface conditions]

Combined Sabatier/ RWGS/Water Electrolysis (Pioneer Ast.)
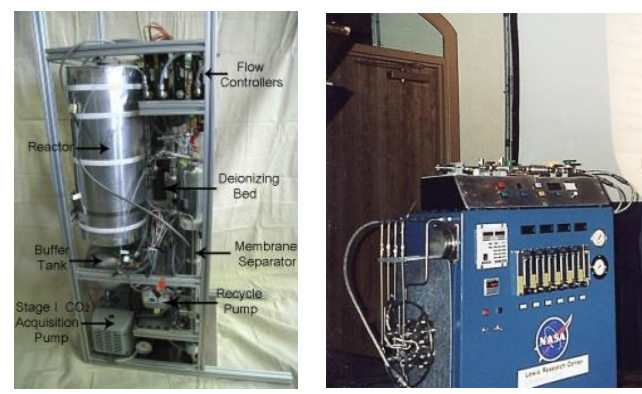

$\mathrm{CO}_{2}$ Electrolysis (GRC)

[Tested under

conference conditions]

Reverse Water Gas Shift/ Water Electrolysis (KSC \& Pioneer Astrobotics)

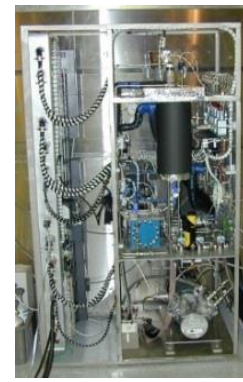

\section{Lunar/Mars Soil Processing}

- $1^{\text {st }}$ Gen $\mathrm{H}_{2}$ Reduction from Regolith Systems (NASA, LMA)

- $2^{\text {nd }}$ Gen MARCO POLO soil processing system (JSC, KSC) - design only

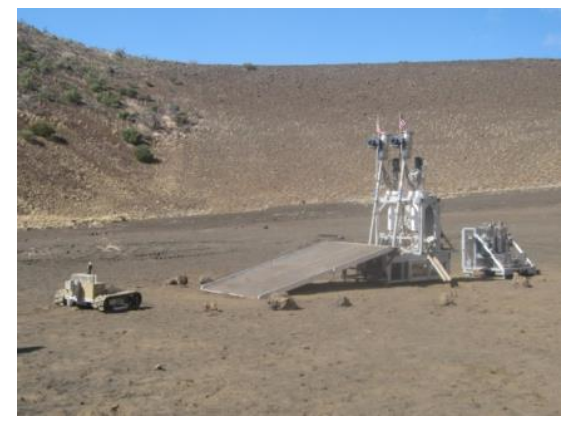

ROxygen $\mathrm{H}_{2}$ Reduction

Water Electrolysis

Cratos Excavator

PILOT $\mathrm{H}_{2}$ Reduction

Water Electrolysis Bucketdrum Excavator

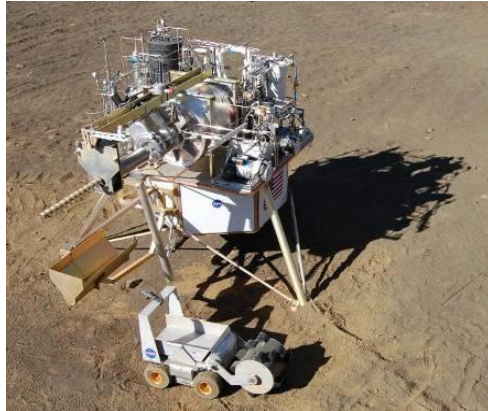

MARCO POLO

- Soil dryer with regolith delivery and avionics

- Water cleanup and storage

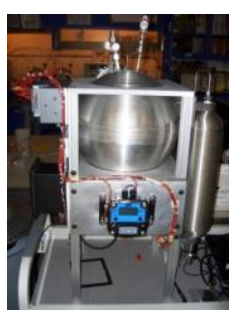




\section{Current ISRU Activities}

\section{SBIR Technologies}

- Mars dust filtration

- $\mathrm{CO}_{2}$ collection and pressurization

- $\mathrm{CO}_{2}$ electrolysis

- Microchannel Sabatier reactors

\section{Mars 2020 ISRU Demo}

- Make $0.02 \mathrm{~kg} / \mathrm{hr} \mathrm{O}_{2} ;<600 \mathrm{~W}$-hrs; 50 sols of operation

\section{Water/Volatile Characterization/Prospecting}

- Resource Prospector Mission - RESOLVE payload
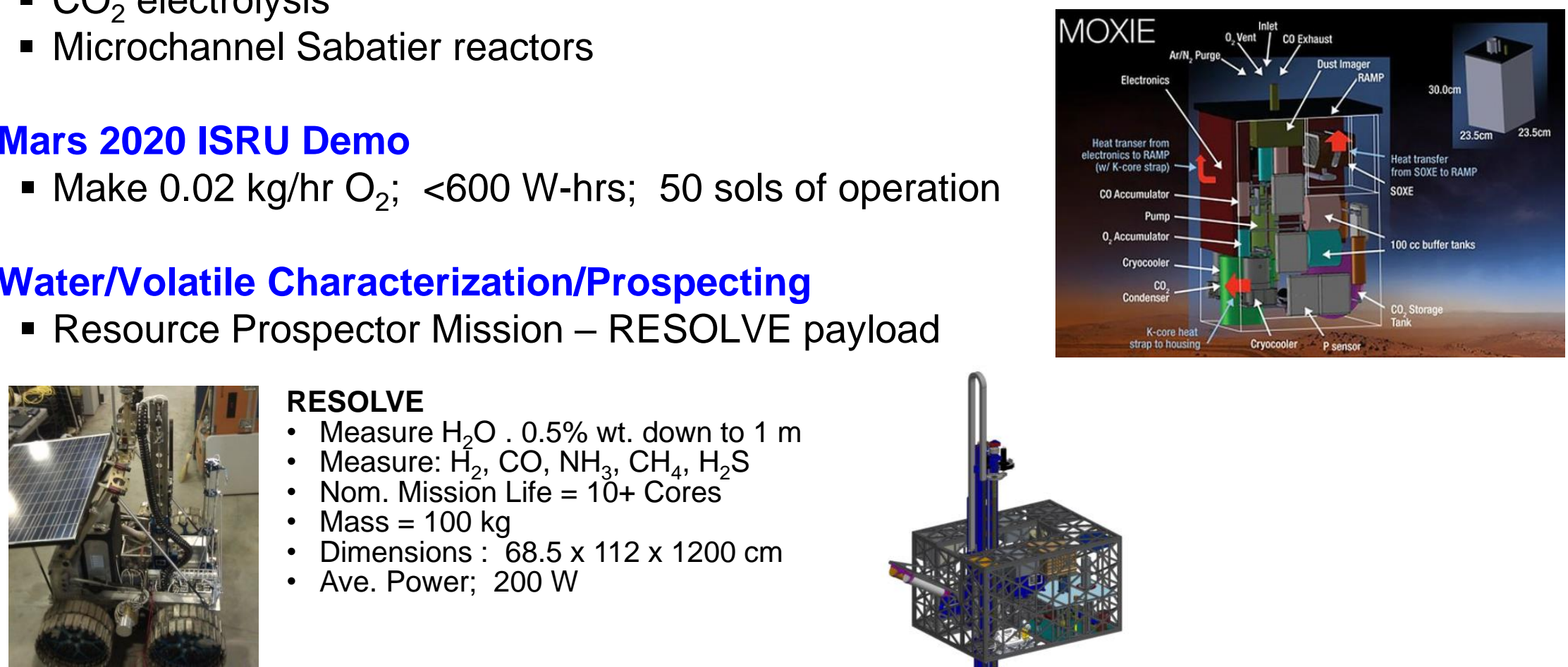

\section{RESOLVE}

- Measure $\mathrm{H}_{2} \mathrm{O}$. 0.5\% wt. down to $1 \mathrm{~m}$

- Measure: $\mathrm{H}_{2}, \mathrm{CO}, \mathrm{NH}_{3}, \mathrm{CH}_{4}, \mathrm{H}_{2} \mathrm{~S}$

- Nom. Mission Life $=10+$ Cores

- Mass $=100 \mathrm{~kg}$

- Dimensions : $68.5 \times 112 \times 1200 \mathrm{~cm}$

- Ave. Power; $200 \mathrm{~W}$

\section{Advanced Exploration Systems (AES)}

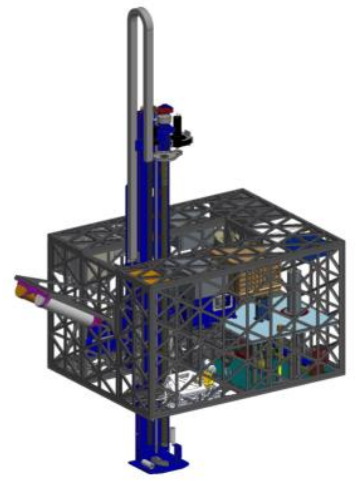

- Trash to Supply Gas; Steam Reforming $/ \mathrm{O}_{2}$ Combustion

- Mars Architecture, Systems, \& Technologies for Exploration \& Resources (MASTER)

- Demonstrate integration and operation of ISRU, Power, and Life Support systems around liquid oxygen and methane under different mission architectures

- Proposed AES new start in FY15 


\section{Results/Conclusions}

- Using Mars atmosphere carbon dioxide $\left(\mathrm{CO}_{2}\right)$ alone is the lowest risk

- $\mathrm{CO}_{2}$ is available everywhere on Mars and no ISRU hardware needs to be deployed

- Multiple options exist to extract oxygen $\left(\mathrm{O}_{2}\right)$ from $\mathrm{CO}_{2}$

- Least amount of hardware and volume of all ISRU options

- While lower in mass, carrying hydrogen $\left(\mathrm{H}_{2}\right)$ from Earth to make $\mathrm{O}_{2}$ /methane $\left(\mathrm{CH}_{4}\right)$ is volumetrically and technically difficult

- $\mathrm{H}_{2}$ is $<1 / 3$ the mass but 3 times the volume compared to $\mathrm{CH}_{4}$ brought from Earth

- Using both Mars atm. $\mathrm{CO}_{2}$ and water $\left(\mathrm{H}_{2} \mathrm{O}\right)$ from the Mars soil is the lowest mass.

- Extra hardware for soil excavation and processing significantly less than mass of ascent fuel brought from Earth

- Power needed for either approach is similar enough not to impact power system greatly

- Mass benefit increases and power difference decreases with increase in water content in soil above $3 \%$ by mass.

- Using both Mars atmosphere $\mathrm{CO}_{2}$ and $\mathrm{H}_{2} \mathrm{O}$ from the Mars soil provides the greatest architecture/mission benefits.

- $100 \%$ of $\mathrm{O}_{2} /$ fuel produced on Mars

- Allows for Mars ascent, surface hoppers, and production of fuel cell reactants for surface mobility

- Water can be used for life support, plant growth, and radiation shielding

- Processes and technologies are similar to lunar water $/ \mathrm{O}_{2}$ extraction from regolith and NEA mining.

- Proving Ground activities on lunar surface, NEAs, and Phobos will reduce risk 


\section{Backup}




\section{How Propellant Production Enables Future Moon \& Mars Missions}

\section{Every $1 \mathrm{~kg}$ of propellant made on Mars saves 7.5 to $11.3 \mathrm{~kg}$ in LEO}

$>25,000 \mathrm{~kg}$ mass savings from propellant production on Mars for ascent $=187,500$ to $282,500 \mathrm{~kg}$ launched into LEO

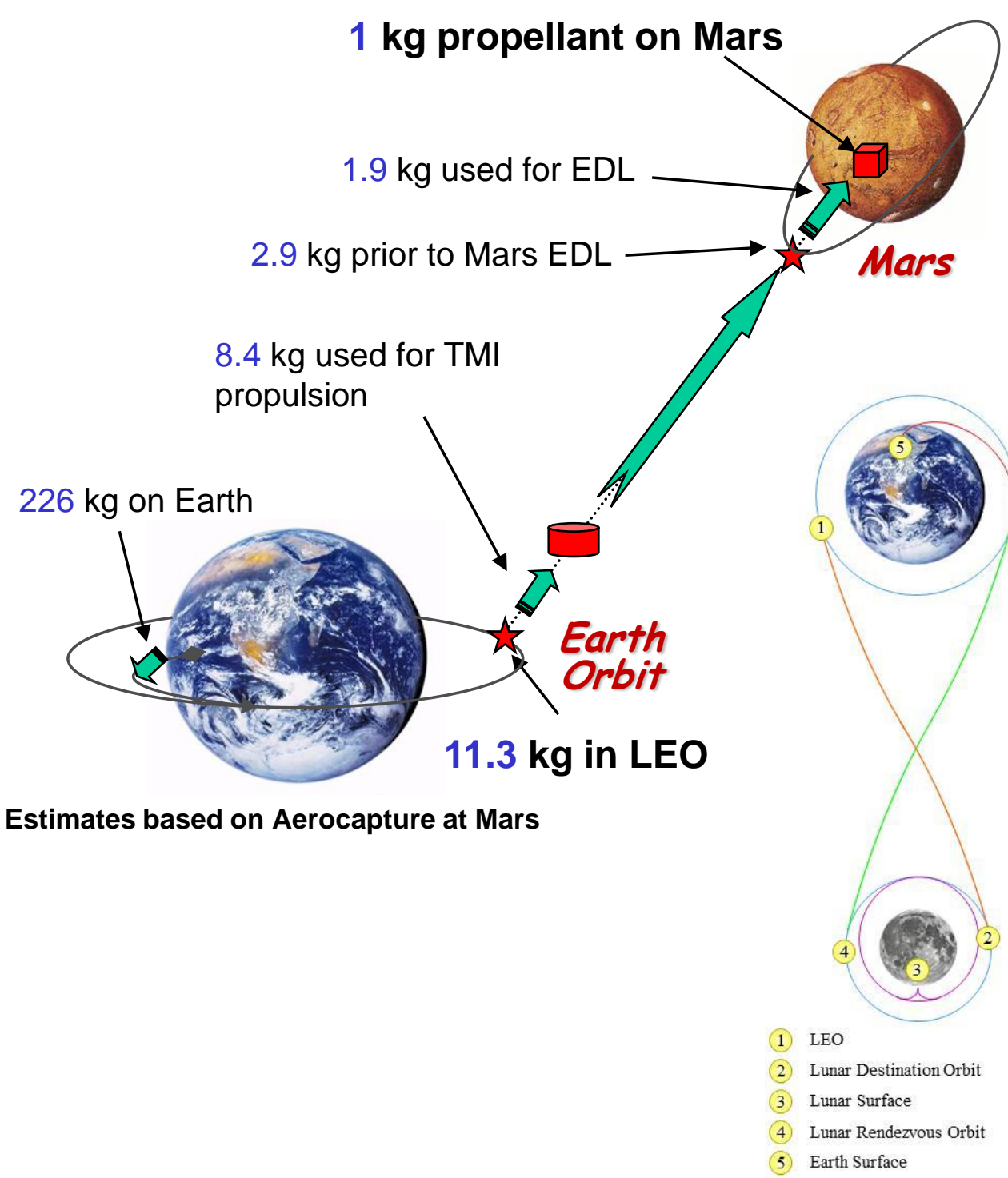

\begin{tabular}{|c|c|c|}
\hline $\begin{array}{l}\text { A Kilogram of Mass } \\
\text { Delivered Here... }\end{array}$ & $\begin{array}{r}\text {...Adds This Much } \\
\text { Initial Architecture } \\
\text { Mass in LEO }\end{array}$ & $\begin{array}{r}\text {...Adds This } \\
\text { Much To the } \\
\text { Launch Pad } \\
\text { Mass }\end{array}$ \\
\hline Ground to LEO & - & $20.4 \mathrm{~kg}$ \\
\hline $\begin{array}{l}\text { LEO to Lunar Orbit } \\
(\# 1 \rightarrow \# 2)\end{array}$ & $4.3 \mathrm{~kg}$ & $87.7 \mathrm{~kg}$ \\
\hline 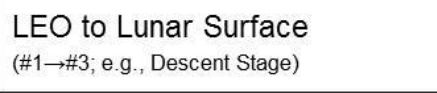 & $7.5 \mathrm{~kg}$ & $153 \mathrm{~kg}$ \\
\hline 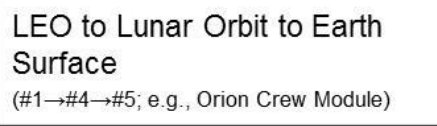 & $9.0 \mathrm{~kg}$ & $183.6 \mathrm{~kg}$ \\
\hline $\begin{array}{l}\text { Lunar Surface to Earth Surface } \\
(\# 3 \rightarrow \# 5 \text {; e.g., Lunar Sample) }\end{array}$ & $12.0 \mathrm{~kg}$ & $244.8 \mathrm{~kg}$ \\
\hline $\begin{array}{l}\text { LEO to Lunar Surface to Lunar } \\
\text { Orbit } \\
(\# 1 \rightarrow \# 3 \rightarrow \# 4 \text {; e.g., Ascent Stage) }\end{array}$ & $14.7 \mathrm{~kg}$ & $300 \mathrm{~kg}$ \\
\hline $\begin{array}{l}\text { LEO to Lunar Surface to Earth } \\
\text { Surface } \\
(\# 1 \rightarrow \# 3 \rightarrow \# 5 \text {; e.g., Crew) }\end{array}$ & $19.4 \mathrm{~kg}$ & $395.8 \mathrm{~kg}$ \\
\hline
\end{tabular}




\section{Why Methane Fuel?}

\section{- Simplicity of ISRU Processing}

- Single step process for methane.

- Two or more steps for most other hydrocarbon fuels

- High processes conversion:

- $>99 \%$ methane product from $\mathrm{CO}_{2}$ in single pass $\left(\right.$ recycle $\mathrm{H}_{2}$ )

- Other fuels (such as Fischer Tropsch) have wide band of hydrocarbons produced; must separate and recycle (increase complexity), or accept (decrease in engine performance)

- Higher propulsion efficiency

- Pros: Higher Isp than most other hydrocarbons

High ox/fuel (O/F) mixture ratio. (Max. benefit for $\mathrm{O}_{2}$ only ISRU)

Clean burning; no coking

- Cons: Methane is lower density than other hydrocarbons

High $\mathrm{H}$-to-C ratio (Min. benefit for Earth provided $\mathrm{H}_{2}$ ISRU options)

\begin{tabular}{|c|c|c|c|c|c|c|c|c|c|c|}
\hline & $\begin{array}{l}\text { NTO/MMH } \\
\text { Press-fed }\end{array}$ & $\begin{array}{c}\mathrm{LO}_{2} / \text { Hydrazine } \\
\text { Press-fed }\end{array}$ & $\begin{array}{c}\mathrm{LO}_{2} / \text { Methane } \\
\text { Press-fed }\end{array}$ & $\begin{array}{c}\mathrm{LO}_{2} / \text { Propane } \\
\text { Press-fed }\end{array}$ & $\begin{array}{c}\mathrm{LO}_{2} / \text { Methanol } \\
\text { Press-fed }\end{array}$ & $\begin{array}{c}\mathrm{LO}_{2} / \text { Ethanol } \\
\text { Press-fed }\end{array}$ & $\begin{array}{c}\mathrm{LO}_{2} / \text { Ethylene } \\
\text { Press-fed }\end{array}$ & $\begin{array}{c}\mathrm{LO}_{2} / \text { Kerosine } \\
\text { Press-fed }\end{array}$ & $\begin{array}{c}\mathrm{LO}_{2} / \mathrm{LH}_{2} \\
\text { Press-fed }\end{array}$ & $\begin{array}{c}\mathrm{LO}_{2} / \mathrm{LH}_{2} \\
\text { Pump-fed }\end{array}$ \\
\hline Isp & 328 & 365 & 362 & 357 & 335 & 340 & 364 & 352 & 441 & 454 \\
\hline MR & 1.9 & 1.0 & 3.5 & 3.25 & 1.5 & 2 & 2.75 & 3.0 & 5.25 & 6.0 \\
\hline Fuel Density $\left(\mathrm{kg} / \mathrm{m}^{3}\right)$ & 880 & 1020 & 422 & $500-580$ & 792 & 789 & 568 & 810 & 71 & 71 \\
\hline Fuel B.P $(\mathrm{K})$ & 360 & 387 & 111.7 & 230.9 & 337.8 & 351.5 & 169.5 & & 20.3 & 20.3 \\
\hline
\end{tabular}

Based on Chamber Pressure $(P c)=500$ psi; Area Ratio $(A R)=150: 1$; Efficiency $=93 \%$

- Higher compatibility with liquid oxygen

- Same technology, insulation, cryocoolers, and tanks used for $\mathrm{CH}_{4}$ as with $\mathrm{LO}_{2}$

- Thermal compatibility of lines and engine/thruster thermal management

Overall, choice of methane fuel is an overall balance of performance, storage, compatibility, and production 